\title{
CRIAÇÕES E PERCEPÇÕES DOCENTES NO ENSINO REMOTO DURANTE A PANDEMIA DE COVID-19: UMA PESQUISA COM OS COTIDIANOS
}

\author{
Vivian Martins ${ }^{\mathrm{i}}$ \\ Bárbara Rodrigues de Castro ${ }^{\mathrm{ii}}$ \\ Michelle Viana Trancoso ${ }^{\mathrm{iii}}$
}

\begin{abstract}
Resumo: Em decorrência da Covid-19, a população mundial entrou em distanciamento social e os processos educativos passaram a ocorrer por meio das tecnologias digitais. Dessa forma, buscamos desenvolver uma pesquisa científica que objetive compreender, a partir das pesquisas com os cotidianos, as criações e as percepções de docentes vivenciando o ensino remoto imposto pelo distanciamento social. As redes sociais da internet, em especial sete comunidades virtuais no Facebook, foram o campo de pesquisa. Entre os dados emergiram narrativas imagéticas e escritas, com criações e percepções de docentes vivenciando o ensino remoto. Propomos a reflexão para outra lógica educacional após essa experiência que está ressignificando nossas vidas.
\end{abstract}

Palavras-chave: Ensino remoto; Narrativas docentes; Pesquisas com os cotidianos; Covid-19.

\section{TEACHING CREATIONS AND PERCEPTIONS IN REMOTE EDUCATION DURING THE COVID-19 PANDEMIC: A RESEARCH WITH EVERYDAY LIFE}

\begin{abstract}
The world population became socially distant and educational processes began to occur through digital technologies as a result of Covid-19. In this way, we seek to develop scientific research that aims to understand, based on research with everyday life, the creations and perceptions of teachers experiencing remote teaching imposed by social distance. The field of research were the internet social networks, especially seven virtual communities on Facebook. Among the data emerged imagery and written narratives, with creations and perceptions of teachers experiencing remote teaching. We propose reflection for other educational logic after this experience that is giving new meaning to our lives.
\end{abstract}

Keywords: Remote teaching; Teaching narratives; Research with everyday life; Covid-19.

\section{Reflexões iniciais}

De nossos medos nasce nossa coragem e em nossas dúvidas vivem nossas certezas. Os sonhos anunciam outra realidade possível e os delírios outra razão. Achados nos esperam nas andanças porque é preciso nos perdermos para nos reencontrar. ${ }^{\text {iv }}$

Eduardo Galeano, 2011 (tradução nossa).

Atualmente, a internet é uma das ferramentas mais utilizadas pelo homem e contribui ainda mais para a construção de um mundo globalizado, onde os saberes diversos são 
compartilhados a uma velocidade que faz com que o planeta pareça menor diante da facilidade de comunicação com o mundo, por exemplo. Tudo isso se deve à ampliação do acesso às tecnologias da informação e comunicação. A popularização e a expansão da internet potencializaram o uso das tecnologias nos diferentes setores da sociedade, trazendo mudanças nas relações econômicas, sociais, culturais, entre outras.

Torna-se importante contextualizar o momento em que a presente pesquisa é desenvolvida. Hoje, estamos em meio a uma pandemia provocada pelo Coronavírus, uma família de vírus que causa infecções respiratórias, provocando a doença denominada COVID19. A COVID-19 pode apresentar diferentes sintomas (não padronizados ainda) e gravidades (desde sintomas mais leves, podendo evoluir até situações mais graves). O novo agente do Coronavírus foi descoberto em 31 de dezembro de 2019, após casos registrados na China. A transmissão acontece de uma pessoa doente para outra pela proximidade, sem o uso de barreiras físicas e por meio de superfícies contaminadas (SAÚDE, 2020). Diante disso e da falta de medicamentos ou vacinas, o distanciamento social tornou-se uma medida necessária para diminuir a transmissão.

Em levantamento realizado pela UNESCO (2020) em 22 de abril do presente ano, os países apresentam diferentes políticas de suspensão de atividades, alguns com escolas fechadas em todo o território, outros com escolas fechadas em algumas localidades e poucos países com escolas abertas, conforme pode ser identificado nas figuras a seguir.

Figura 1 - Monitoramento mundial do fechamento de escolas devido à COVID-19

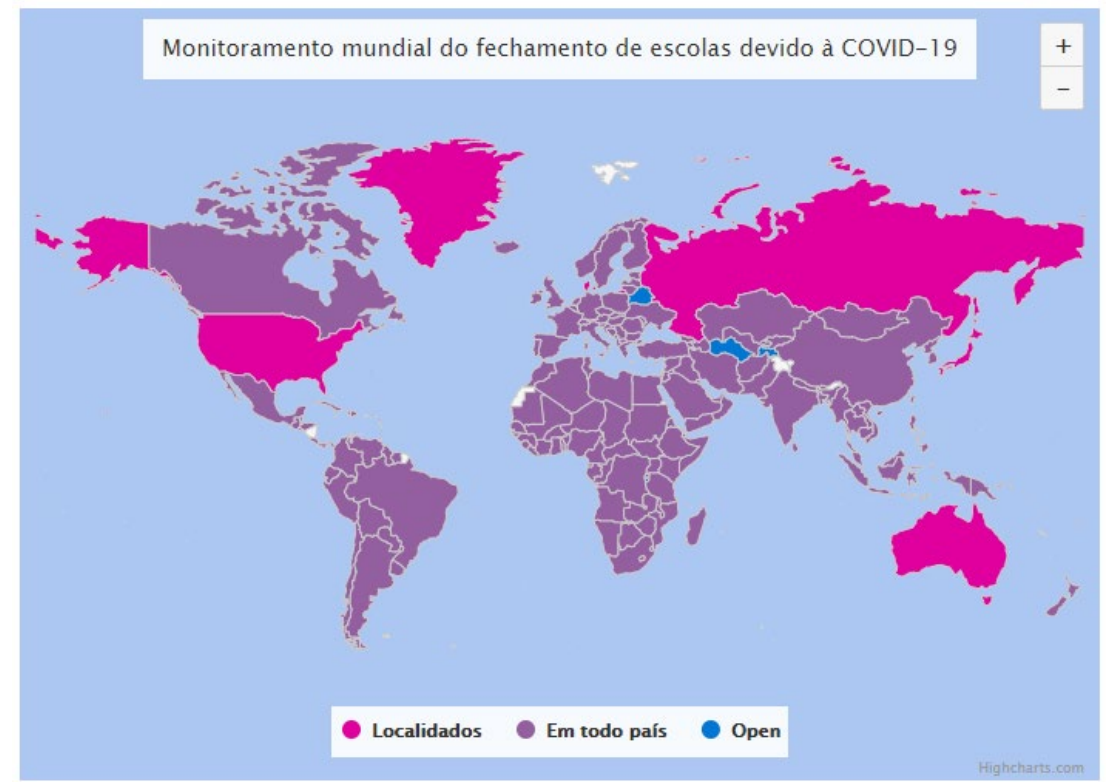

Fonte: UNESCO, 2020. 
Figura 2 - Destaque para os dados brasileiros no monitoramento mundial do fechamento de escolas devido à COVID-19

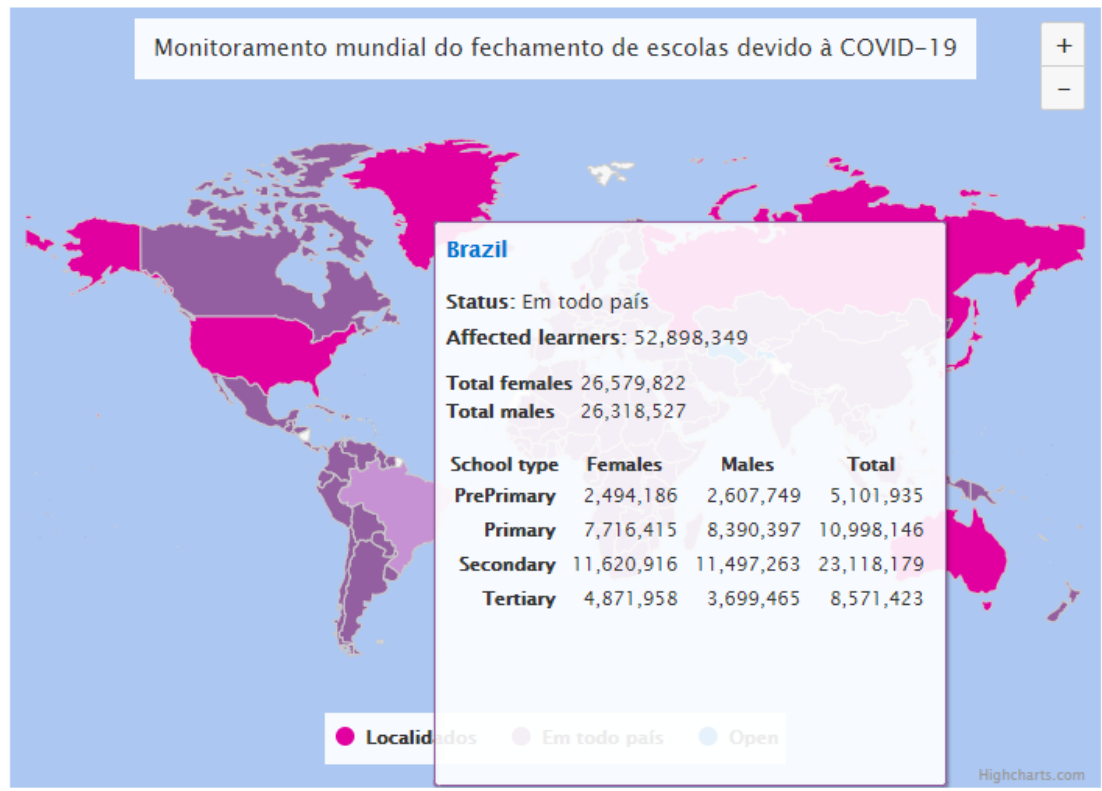

Fonte: UNESCO, 2020.

Frente a essa conjuntura, desenvolvemos uma pesquisa que objetiva compreender, a partir das pesquisas com os cotidianos, as criações e as percepções de docentes vivenciando o ensino remoto imposto pelo distanciamento social. Pra tal, realizamos, inicialmente, um estudo sobre a relação entre a tecnologia e a educação, para entender as características que o ensino remoto pode apresentar. O cenário na educação aponta para o ensino remoto como forma de dar continuidade aos processos educativos. Para entender o contexto brasileiro, realizamos um levantamento de legislações, práticas dos Estados e Distrito Federal, com um aprofundamento para os Estados da região Sudeste, localidade onde a pesquisa está sendo realizada. Dessa forma, poderíamos pensar a realidade dos praticantes ${ }^{\mathrm{v}}$ da presente pesquisa, docentes criadores de narrativas digitais em rede.

A opção método-epistemológica foi a das pesquisas com os cotidianos (ALVES, 2001; ANDRADE; CALDAS; ALVES, 2019) indo além dos pressupostos limitantes da ciência moderna; mergulhando nas lógicas cotidianas para além da crítica, valorizando os saberes produzidos por praticantes (CERTEAU, 1994) a partir de suas criações ordinárias; com uma sólida base de apoio para questionar o que está posto; dialogando com nossos intercessores (narrativas que nos impulsionam a articular ideias e compreender aquilo que pesquisamos), denominados como personagens conceituais (ANDRADE; CALDAS; ALVES, 2019); a valorização das narrativas provenientes do campo; uma escrita que narra os acontecimentos 
humanos; a pesquisa como um tecer em conjunto e sem rotas fixadas (afinal, precisamos nos perder para nos encontrar, como diria Galeano), entre outros movimentos da pesquisa.

Como espaço de mergulho, ou campo de pesquisa, adotamos as redes sociais da internet, em especial sete comunidades virtuais no Facebook: 1) academia pandêmica, 2) Educação vagas, 3) Vagas para professores RJ, 4) Ensino na pandemia - Ciência e cia, 5) Professores e profissionais da educação RJ, 6) Profissão=Professora e 7) Vagas para educador: Professor, Instrutor, tutor, D.I, Conteudista, Pedagogo. Os referidos grupos foram escolhidos por contar com uma grande quantidade de narrativas de professores que relatam situações cotidianas e práticas pedagógicas.

O presente artigo foi desenvolvido em tópicos específicos: esta introdução, que apresentou o contexto, o objetivo e as opções teórico-metodológicas da pesquisa; na seção 2, será discutido o modo como as tecnologias transversalizam nossas ações educacionais cotidianas; na seção 3, será delineado um breve panorama do ensino remoto no Brasil em distanciamento social; na seção 4 , serão explicitados os princípios metodológicos e epistemológicos que percorreremos no desenvolvimento da pesquisa, com as pesquisas com os cotidianos; na seção 5, serão apresentadas as narrativas dos praticantes e os resultados da pesquisa; e, por fim, serão desenvolvidas algumas considerações finais, com a síntese dos conteúdos abordados.

\section{Desafios e possibilidades da relação entre tecnologia e educação}

As interfaces tecnológicas vêm influenciando todas as áreas no mundo contemporâneo, desde as mudanças no meio social como também no espaço educacional, exigindo dos envolvidos no contexto escolar a renovação dos aspectos pedagógicos, administrativos e de gestão. O fato é que muitas das nossas escolas públicas não acompanharam o desenvolvimento das tecnologias da informação e comunicação e, embora haja um processo de informatização nas unidades de ensino, estamos longe de chegar a uma integração plena da educação com o uso dos meios tecnológicos (SILVA, 2014). Antes de tudo, é preciso deixar claro que esse atraso tecnológico não é uma questão apenas da escola enquanto instituição, ele é parte dos problemas existentes no nosso sistema educacional e resultado de ações políticas que, historicamente, não têm priorizado a educação pública como uma questão fundamental para o desenvolvimento.

Com a cibercultura, as tecnologias ganham cada vez mais espaço em nosso cotidiano e nas escolas não seria diferente: vivemos uma era em que muitas crianças já chegam às escolas 
dominando o manuseio de aparelhos eletrônicos e ensinando adultos a "navegar" na internet. Conforme pode ser visto nas palavras de Palfrey e Gasser (2011, p. 269),

Aprender é muito diferente para os jovens de hoje do que era 30 anos atrás. A internet está mudando a maneira com que as crianças coletam e processam informações em todos os aspectos de suas vidas. Para os Nativos Digitais, "pesquisa", muito provavelmente, significa uma busca no Google mais do que uma ida até a biblioteca. (...) Eles raramente, se é que alguma vez, compram o jornal em papel; em vez disso, surfam por enormes quantidades de notícias e outras informações on line.

Uma parte dos alunos não encontra dificuldades em realizar pesquisas com a facilidade de acesso aos dispositivos móveis e à conexão, pois não precisam sair de suas casas, tampouco, ler vários livros para ter informação sobre um assunto. Muitas informações estão nas palmas das mãos dos estudantes e podem ser encontradas em uma velocidade que não imaginávamos que existiria há poucas décadas atrás. Contudo, informação não significa conhecimento, é necessário um processo de significação e de formação para saber lidar com a quantidade enorme de informação, que muitas vezes não apresenta fonte confiável ou é uma notícia falsa fabricada por pessoas disseminadoras das chamadas Fake News. Educar para a mídia (DUARTE, ELEÁ, 2016) faz parte de uma das atribuições da docência contemporânea.

Ainda segundo Palfrey e Gasser (2011, p.277), “devemos experimentar formas em que a tecnologia deva ser parte do currículo do dia a dia nas escolas - mas apenas onde ela cabe", pois inserir a tecnologia no cotidiano escolar não deveria significar o seu uso indiscriminado, mas sim mostrar às crianças e aos adolescentes que ela serve para nos ajudar na aquisição de conhecimento, devendo ser utilizada com moderação e responsabilidade.

Em diferentes componentes curriculares, encontramos saberes que devem ser ensinados sem telas e conexões com a rede. Não podemos generalizar sobre qual prática pedagógica é mais adequada, pois a complexidade da educação nos faz refletir que os cotidianos são diversos, múltiplos e repletos de surpresas. O diálogo, independente de onde esteja sendo realizado (por meios tecnológicos ou não), ainda é umas das formas mais eficazes de proporcionar o aprendizado, a troca, o questionamento e a emergência de diferentes opiniões. Portanto, interessa reunir diversas metodologias de ensino, selecionando de acordo com o que o cotidiano da sala de aula apresenta, ao invés de excluir ou incluir somente um método.

A escola, para fazer cumprir sua responsabilidade social de educar e formar os novos cidadãos precisa contar com professores que estejam dispostos a captar, a entender e a utilizar as novas linguagens dos meios de informação e comunicação a serviço de sua prática pedagógica que deve ser compreendida 
como uma forma específica de práxis, portanto, prática social que envolve teoria e prática, própria da prática educativa (SALDANHA; WERLANG, 2017, p. 26).

Diante disso, os professores precisam lidar com essa nova geração de alunos, pois eles trazem consigo hábitos de acesso à informação em rede. É preciso estar coerente com o momento, o contexto e os perfis dos nossos alunos para uma aula de acordo com a realidade que nos é apresentada. Sabemos que a realidade docente é repleta de desafios, mas é primordial que o docente proporcione a possibilidade do aluno desenvolver seu próprio caminho para o conhecimento com as interfaces que emergem culturalmente.

As novas tecnologias fornecem instrumentos imprescindíveis para essa empreitada, pois os recursos que elas disponibilizam são capazes de facilitar e agilizar a vida da sociedade contemporânea e de fornecer formação educacional, (...), permitindo, assim, a atualização de conhecimentos, a socialização de experiências e a aprendizagem através dos recursos tecnológicos (SOUSA; MOITA; CARVALHO, 2008, p. 133).

Com isso, jogos, aplicativos e sites diversos disponibilizados on-line oferecem ludicidade e auxiliam professores e alunos na interação e na construção do conhecimento de maneira criativa e prazerosa. Essas interfaces, muitas vezes utilizadas também nas casas dos alunos e em celulares, são um grande potencializador de aprendizagens, visto que os alunos aprendem brincando e os professores passam a refinar suas buscas de atividades lúdicas diferenciadas, deixando sua aula mais enriquecida.

Para Freire (1987), educar é um ato político que visa liberdade, autonomia, transformação da visão de mundo e deve estar fundamentada em uma perspectiva emancipatória. Trata-se de uma educação repleta de significações, que faz com que o estudante aprenda a partir de situações concretas de suas experiências de vida. A finalidade da institucionalização do ensino por meio da escola é a de proporcionar um ambiente que organize o conhecimento e que favoreça o aprendizado de uma forma planejada, pois é interessante contar com um lugar que ensine os conhecimentos legitimados pela sociedade e, para isso, a escola desempenha a sua função social como uma das formadoras de sujeitos, inclusive para o uso consciente das tecnologias digitais. Na impossibilidade de ter a escola como a conhecemos, muitas instituições aderiram ao ensino remoto, a seguir apresentaremos um panorama inicial sobre como essa prática tem se delineado no Brasil. 


\section{Ensino remoto no contexto brasileiro: um breve panorama}

A pandemia ocasionada pela COVID-19 alterou significativamente a vida do brasileiro, impondo um distanciamento social que afetou diretamente a rotina escolar. Na tentativa de conter a propagação do vírus e resguardar a saúde de professores, aluno e funcionários, escolas foram fechadas e muitas instituições implantaram o ensino remoto, como forma de dar continuidade aos processos educativos. Governo Federal, Estados e Municípios publicaram legislações emergenciais para normatizar o ensino remoto. Apresentaremos um breve panorama da situação com a seleção do parecer nacional, das legislações dos Estados mais próximos e do Município em que as pesquisadoras estão situadas.

Em 28 de abril de 2020, o Conselho Nacional de Educação publicou parecer ${ }^{\text {vi }}$ favorável à possibilidade de cômputo de atividades pedagógicas não presenciais para fins de cumprimento da carga horária mínima anual, além da proposta de parecer sobre a reorganização do Calendário Escolar, em razão da Pandemia da COVID-19. Entre outras informações, o documento recomenda que escolas orientem famílias e alunos no planejamento de estudos e que as atividades não presenciais sejam realizadas com mediadores familiares, entendendo que as instituições ou redes de ensino possuem autonomia.

Homologado pelo Ministério da Educação (MEC), em $1^{\circ}$ de junho de $2020^{\text {vii }}$, as alterações do parecer do CNE para a homologação ficaram por conta do tema avaliação e exames. Na nota técnica do MEC viii, consta que a avaliação precisa "garantir uma avaliação equilibrada dos estudantes em função das diferentes situações que serão enfrentadas em cada sistema de ensino, assegurando as mesmas oportunidades a todos que participam das avaliações em âmbitos municipal, estadual e nacional” (MINISTÉRIO DA EDUCAÇÃO, 2020, p. 2).

Entretanto, a homologação do parecer pelo MEC não provocou uma ação coordenada entre os Estados e o Distrito Federal. De acordo com levantamento nacional publicado pelo G1 (2020), "todos os estados e o DF adotaram atividades remotas, mas cada estado adotou uma maneira de repassar o conteúdo - plataformas virtuais, sites, TV aberta e até por meio do WhatsApp”. E, “Além do DF, 7 estados declararam que não vão usar a educação remota como carga horária do ano letivo: AL, BA, DF, ES, MT, PA, SE e TO. PE não decidiu ainda; RO e RJ não responderam". Acreditamos que o último caso relatado seja o mais adequado, afinal, tendo em vista a falta de acesso de muitos estudantes ao conteúdo proposto, substituir a carga horária do ano letivo pelo ensino remoto prejudicaria as classes populares, e aqueles que não tiveram a oportunidade de participar dos processos educativos durante a pandemia, poderão ter 
acesso ao conteúdo no retorno presencial às aulas. Diante de tal cenário, realizamos uma pesquisa para compreender como estão desenvolvendo o ensino remoto nos Estados próximos.

De acordo com o site da Secretaria da Educação (Seduc) ${ }^{\mathrm{ix}}$, o Estado de São Paulo antecipou o período de férias e recesso escolar, assim como disponibilizou aulas ao vivo, videoaulas e outros conteúdos pedagógicos por meio do Centro de Mídias da Educação de SP, disponível em plataforma digital e no canal digital aberto de televisão 2.3 - TV Cultura Educação, para estudantes de ensino fundamental e médio. A proposta apresenta uma programação de 10 horas de conteúdo escolar, sem precisar usar a internet de casa ou o pacote de dados móveis do celular do aluno, tendo em vista o futuro contrato entre a Seduc e as quatro maiores operadoras de telefonia do Brasil para patrocinar internet para alunos e professores da rede, sem qualquer custo para os mesmos. A informação disponibilizada no site da Secretaria da Educação é de que a partir de 22 de abril de 2020, as aulas contarão como dias letivos. A pasta do governo do Estado também tem intenção de produzir conteúdo para a educação infantil em parceria com a Secretaria Municipal de Educação.

Já no Estado do Espírito Santo, a Secretaria de Estado de Educação dispôs na Resolução CEE N 5.447 de 20 de março $2020^{\mathrm{x}}$ ações de regime emergencial de aulas não presenciais, tais como: planejar e elaborar ações pedagógicas e administrativas durante o período de distanciamento social, viabilizando material de estudo e aprendizagem de fácil acesso; preparar material específico para cada etapa e modalidade de ensino, como: videoaulas, conteúdos organizados em plataformas virtuais de ensino e aprendizagem, redes sociais e correio eletrônico; organizar avaliações dos conteúdos ministrados durante o regime emergencial de aulas não presenciais, para serem aplicadas na ocasião do retorno às aulas presenciais. Observamos o foco no conteúdo e não nos processos educativos. Assim como o estado de São Paulo, também houve antecipação do recesso escolar.

O Conselho Estadual de Educação do Estado (CEE) de Minas Gerais também reorganizou as atividades escolares do Sistema Estadual de Ensino, devido à pandemia do COVID-19. Segundo o $\mathrm{CEE}^{\mathrm{xi}}$,

quaisquer componentes curriculares poderão ser trabalhados em ensino remoto, nas escolas que puderem oferecê-lo, observadas as possibilidades de acesso, pelos estudantes e professores, deverão ser registradas e, eventualmente, comprovadas perante as autoridades competentes, e farão parte do total das 800 (oitocentas) horas de atividade escolar obrigatória" (CEE-MG, 2020). 
A proposição do Estado de Minas Gerais é para "reposição de aulas de forma presencial, formas de realização de atividades escolares não presenciais, adotando regime remoto, via internet, se possível" (CEE-MG, 2020). Entretanto, o sindicato dos professores assegurou, na Justiça, a paralisação do trabalho remoto por meio de liminar ${ }^{x i i}$.

No Estado do Rio de Janeiro, o Conselho Estadual de Educação orienta as instituições integrantes do Sistema Estadual de Ensino sobre o desenvolvimento das atividades escolares não presenciais, durante o afastamento social com a deliberação $\mathrm{CEE} \mathrm{N}^{\circ} 376$, de 23 de março de $2020^{\text {xiii }}$. O documento autoriza a reorganização das atividades escolares, a partir de seus projetos pedagógicos, a serem realizadas pelos estudantes e profissionais da educação em regime especial domiciliar. Dos Estados pesquisados, o Rio de Janeiro é o único que determina que na educação infantil deverá haver reposição das aulas somente de forma presencial, de modo que cada aluno esteja apto a cumprir o mínimo de $60 \%$ de presença dos 200 dias letivos, conforme determina o art. 31, inciso IV, da Lei de Diretrizes e Bases (LDB). Entretanto, os Conselhos Municipais de Educação podem ter normas próprias e escolher se adotam essa medida ou não. O CEE também estabelece que as instituições da educação básica devem, com a participação de seu corpo docente, planejar e organizar as atividades escolares, a serem realizadas pelos estudantes fora da instituição.

A Secretaria de Educação da capital fluminense lançou um aplicativo com conteúdo pedagógico para os estudantes de todos os segmentos, contendo aulas específicas já divididas por segmento, da pré-escola à educação de jovens e adultos. Os estudantes e seus familiares podem acessar o aplicativo a partir de celulares e computadores. O conteúdo do material pedagógico também está disponível no site da MultiRio e professores ministram aulas por meio de redes sociais. Segundo a secretária da pasta, “a SME também está desenvolvendo conteúdos específicos para a plataforma de aulas digitais da Microsoft TEAMS. A plataforma de matemática, acessível pelo sistema MATIFIC, também está disponível para os alunos. A ampliação de rede de internet para uso de professores e alunos já foi solicitada para facilitar os acessos." "xiv . No âmbito da $8^{\text {a }}$ Coordenadoria Regional de Educação, foi criado o site Material de Complementação $8^{\mathrm{a}} \mathrm{CRE}$, onde professores que atuam em todos os segmentos contribuem com vídeos explicativos acerca dos materiais disponibilizados no aplicativo, semanalmente ${ }^{\mathrm{xv}}$.

Diante de tais regulamentações, uma grande quantidade de professores encontra-se envolvida no ensino remoto. Optamos por utilizar o termo ensino remoto ao invés de educação a distância (como pode ser encontrado em divulgações e notícias em diversos espaços) por acreditarmos que educação a distância não se encaixa no que está sendo realizado atualmente, 
em razão de ser uma modalidade de ensino com regulamentação própria, metodologia específica e ambiências formativas idealizadas exclusivamente para essa modalidade, diferente das propostas aligeiradas e adaptadas emergencialmente que encontramos nesse momento de excepcionalidade.

A controvérsia é tamanha que cidadãos e entidades estão procurando a Justiça contra a obrigatoriedade do ensino remoto, para que não seja contabilizado como horas letivas obrigatórias $^{\mathrm{xvi}}$. Partindo desse debate, buscamos compreender as invenções cotidianas realizadas por professores em meio ao distanciamento social imposto pela Covid-19. A partir das pesquisas com os cotidianos, as narrativas digitais nas redes sociais da internet são compreendidas como personagens conceituais, possibilitando a compreensão das práticas realizadas atualmente. Apresentamos, a seguir, o método e a epistemologia que direcionaram a investigação.

\title{
As pesquisas com os cotidianos: rotas, caminhos e desvios
}

\begin{abstract}
Nas pesquisas com os cotidianos partimos da ideia de que pensar as práticas cotidianas de viver dentro e para além das macro-negociações políticas e econômicas permite nos aproximar da complexidade da vida sem abrir mão de todas as redes que formamos e nas quais nos formamos. Neste sentido, nunca buscamos estudar sobre os cotidianos, mas estudar nos/dos/com os cotidianos, assumindo a nossa total implicação neste processo, entendendonos, sempre, como neles mergulhadas. Estudar e pesquisar com os cotidianos de pessoas comuns, com as histórias comuns que nos são contadas - porque nessas pesquisas as narrativas (todos os sons) e imagens contam - encontrando nestas, sentimentos e 'conhecimentossignificações' que seus 'praticantespensantes' (OLIVEIRA, 2012) criam, exigiu admitir a riqueza e complexidade desses 'espaçostempos' (ANDRADE; CALDAS; ALVES, 2019, p. 19).
\end{abstract}

As pesquisas com os cotidianos configuram-se uma opção teórica-metodológica e epistemológica para pensar como conhecimentos são criados cotidianamente. No Brasil, há mais de 20 anos, pesquisadores inspirados em Lefebvre (1992), Deleuze e Guattari (1992), Certeau (1994) e outros, investem em compreender os cotidianos. Estamos interessados nas maneiras de fazer dos praticantes culturais, as táticas, os usos e as astúcias do cidadão comum, ou ordinário (CERTEAU, 1994), em especial nas diversas redes educativas onde nos formamos.

Alves $(2001 ; 2008)$ elencou 5 movimentos necessários para as pesquisas nos/dos/com os cotidianos, são eles: o sentimento do mundo, virar de ponta cabeça, beber em todas as fontes, narrar a vida e literaturizar a ciência e ecce femina. Em 2019, Andrade, Caldas e Alves 
atualizaram esses movimentos e inauguraram mais um, são eles: o sentimento do mundo, ir sempre além do já sabido, criar nossos "personagens conceituais", narrar a vida e literaturizar a ciência, ecce femina e a circulação dos 'conhecimentossignificações' como necessidade. Detalharemos os movimentos atualizados, sem, contudo, desconsiderar os anteriores, pois eles estão enraizados em nossas práticas cotidianistas.

O primeiro movimento foi mantido, o sentimento do mundo, que impulsiona o mergulho com todos os sentidos no cotidiano arredio e complicado, sentindo o mundo e não somente olhando para ele, sem o distanciamento científico que presumia a ciência moderna. No movimento ir sempre além do já sabido, as autoras refletem que para vir o novo é preciso o confronto com o que já foi feito, de forma a "conhecer o melhor possível o que existe - o que se escreveu, o que se pensa - pois só assim é possível negá-lo, mostrar seus limites e ir adiante" (ANDRADE; CALDAS; ALVES, 2019, p. 26).

No terceiro movimento, criar nossos "personagens conceituais", as autoras dialogam com Deleuze e Guattari (1992) que valorizam a criação de intercessores para disparar reflexões e contribuir para a compreensão do tema pesquisado. No quarto movimento, narrar a vida e literaturizar a ciência, as autoras salientam para a necessidade de narrar os acontecimentos com diferentes referenciais e espaçostempos ${ }^{x v i i}$ e não necessariamente o âmbito acadêmico, indo além de textos escritos ou científicos.

No movimento Ecce femina, as autoras chamam atenção para o fato de que o mais importante das nossas pesquisas cotidianistas, o núcleo central, são os praticantes culturais, com suas criações, interlocuções, memórias, narrativas, paixões e significações que nos despertam para diferentes compreensões de mundo. E, por fim, o movimento a circulação dos 'conhecimentossignificações' como necessidade, entendendo que a circulação da produção cotidiana vai além da comunicação científica, as ressonâncias de uma criação auxiliam para que autores ressignifiquem suas práticas. Os diálogos originários de uma publicação (científica ou não), com percepções, entendimentos ou até críticas nos oferecem contribuições relevantes para a continuidade das pesquisas.

Em consonância com os princípios metodológicos já expostos nesse estudo, é importante destacar que não vamos ao campo, como quem vai a um lugar estranho 'colher' informações. Estamos no campo, praticando a vida cotidiana junto com os praticantes dessa pesquisa - mergulhados, atravessados, afetados. Somos, nesse caso, parte integrante daquilo que pretendemos investigar. Habitamos as redes sociais, juntamente com os praticantes [...] (COLACIQUE, 2018, p. 39). 
A percepção de Colacique (2018) é a mesma que direciona nosso caminhar na pesquisa, tornando o fazer científico uma construção humana e cultural e não impessoal, neutra, objetiva e distante. Alguns princípios das pesquisas com os cotidianos são: a compreensão de que os fenômenos que transversalizam as práticas educacionais devem ser entendidos a partir de uma multiplicidade de olhares e significações; a necessidade de o pesquisador assumir a imprevisibilidade; a importância que os sujeitos da pesquisa possuem; a pesquisa como processo, o caminhar e não somente o resultado; a necessidade de assumir os limites teóricos e metodológicos; e a percepção da complexidade dos espaçostempos escolares, já que a nossa leitura não pode ser compreendida como a totalidade dos cotidianos, múltiplos enredamentos os atravessam.

A opção por prestigiar as narrativas dos praticantes a respeito de suas inquietações, relatos de práticas pedagógicas, desabafos, compartilhamento de informações, entre outros, objetiva compreender o fenômeno que se apresenta atualmente. Entendendo que nas redes educativas onde esses professores se encontram há uma grande produção de conhecimento, operações, usos, táticas e desvios de usuários (CERTEAU, 1994) que promovem entendimentos únicos sobre o objeto de pesquisa.

Neste movimento, se reconhece que o mais importante nas pesquisas com os cotidianos é identificar e incorporar os 'praticantespensantes' com suas memórias de suas tão diferentes criações culturais e curriculares, tratando dos 'conhecimentossignificações' que produzem em suas tantas narrativas, como respostas às suas necessidades cotidianas, com seus modos de compreender o mundo e nele agir, nas tantas redes educativas que formam e nas quais se formam (ANDRADE, CALDAS, ALVES, 2019, p. 34).

As narrativas dos praticantes serão fundamentais para compreender o fenômeno que se apresenta como objeto de estudo. Não interpretaremos as narrativas dos praticantes a nosso belprazer, para encontrar nas narrativas noções que nos faltam ou articulá-las como julgar melhor. Mas para dar sentido ao que estamos vivenciando, sem hierarquização do saber do praticante ao saber científico. Na consciência do inacabamento, já que a plena explicação de um fenômeno às vezes nos impede de pensar sobre a sua complexidade.

Utilizamos o aplicativo Whatsapp para a composição do diário de campo e para a organização dos dados. Criamos um grupo entre as pesquisadoras, onde eram enviados registros necessários para a elaboração da pesquisa, como publicações científicas, notícias e regulamentações necessárias à compreensão do contexto atual, reflexões das pesquisadoras para a elaboração do artigo, narrativas dos praticantes ciberculturais envolvidos no campo, imagens 
divulgadas em rede, observações de interações mediadas pelas ferramentas comunicacionais, entre outros dados, de forma a reunir em um espaço único para que não se perdesse nada. Foram selecionadas 105 narrativas escritas para a análise final, alguns relatos bem extensos e outros mais sucintos. Ressaltamos que sem um espaço para a organização do vasto material e a sistematização dos dados, eles poderiam ser facilmente perdidos.

Vale ressaltar que o rigor desta investigação encontra-se na ética e no respeito aos praticantes da pesquisa, nas escolhas para a produção do conhecimento, no quadro teórico coerente com as práticas e na avaliação permanente das etapas da pesquisa. Escolhas rigorosas são feitas ao trazer as narrativas dos praticantes para o estudo. Todo trabalho intelectual é uma produção subjetiva, com seleções, delineamentos e atravessamentos que afetam o pesquisador. São opções para melhor compreender o objeto de pesquisa. Macedo, Galeffi e Pimentel (2009) acreditam que a qualidade dos efeitos de um método esteja nas reverberações realizadas nas vidas cotidianas dos indivíduos e das sociedades.

A análise e a triangulação dos dados emergentes do campo de pesquisa dispõem de alguns passos importantes, entrelaçamos a teoria com as narrativas dos professores e as significações dos pesquisadores, a partir dos aspectos observados no campo de pesquisa. Dessa forma, é possível organizar, analisar, categorizar e descrever tendências observadas entre as diversas interações ao longo da investigação. Diante de tal movimento, buscamos compreender as criações de professores compartilhadas em redes digitais, reflexões que serão abordadas na sequência.

\section{Criações e percepções docentes em meio ao distanciamento social e ao ensino remoto}

Essa crise veio para repensarmos profundamente tudo que era, até então, estabelecido. Tudo está diferente e possivelmente nunca será igual. Essa fase de adaptação vai acontecer com todos nós, mas se todo esse processo acontecer com empatia, respeito e reconhecimento, vai ficar mais fácil para todo mundo. Me solidarizo com vc professora. MUITA FORÇA, VC É 10!

Denise Lessa, 2020.

Iniciamos as reflexões desse tópico com uma bela narrativa de praticante, personagem conceitual da nossa pesquisa. Com narrativas assim, buscamos apresentar a percepção dos docentes a respeito desse momento excepcional que estamos vivendo, e os caminhos que precisaremos pensar para uma educação pós-pandemia. Ademais, observamos uma diversidade de criações ou táticas que os praticantes ciberculturais vêm desenvolvendo na internet para colocar em prática experiências formativas mediadas pelo digital em rede em meio a uma 
pandemia, contexto em que, de forma emergencial, suas práticas precisaram ser ressignificadas. As narrativas e as imagens criadas por esses praticantes são entendidas como os personagens conceituais desta pesquisa, pois, nas palavras de Alves e Andrade (2013),

[...] fomos levados, nas "conversas" de nosso grupo de pesquisa, a compreender as imagens e as narrativas como "personagens conceituais" (DELEUZE e GUATTARI, 1992), ou seja, como aquele que "fazemos falar e perguntar por nós", como Deleuze indica que Descartes faz com seu personagem "o Idiota". Ou seja, como o "outro" com que "conversamos" permanentemente, que nos vai colocando perguntas, que nos obriga a pensar para fazer caminhar o pensamento e com o qual criamos conhecimentossignificações com tudo o que vamos acumulando, organizando e articulando ao desenvolver as pesquisas (ALVES; ANDRADE, 2013, p. 3).

Gostaríamos de alertar que não pretendemos trazer uma abordagem completa sobre a temática, pois escolhas são feitas, direcionadas para as criações e a astúcias dos professores apesar de todas as adversidades. Sabemos das dificuldades do momento e o contexto brasileiro, eles não foram ignorados na pesquisa, mas foram desenvolvidos em outra parte do estudo. $\mathrm{O}$ presente trabalho busca agregar uma fonte para reflexão por todos nós, o recorte para os temas leva em consideração as experiências de vida e de formação dos pesquisadores e em um período curto de tempo (três meses) do distanciamento social.

Inicialmente, como forma de contextualizar o momento atual, anunciamos uma breve apresentação de narrativas escritas por docentes em comunidades digitais no Facebook, contando suas realidades durante o ensino remoto.

Patrícia Oliveira - Muitas coisas boas acontecendo. Estamos com saúde, estou trabalhando em casa. A jornada triplicou, aulas online, fazendo slides constantemente. Ainda sobra um tempinho para ajudar alguns colegas que não adaptaram nessa nova modalidade. Estou ensinando muito, mas aprendendo muito também. Vou sair desse momento muito fortalecida. Beijos para nós professores.

Sandra Cavalcante - O cenário é complexo, sem precedentes... e, no Brasil, aterrador. Que caminhos podemos (ou devemos) seguir de forma a não esperar a morte em uma velha trincheira da qual, parece, não vemos saída? Será que não há saída de fato? Como podemos fazer para tornar essa face da pandemia, da negação de direitos humanos, visível, em pauta, em discussão, na roda, necessariamente posta na/para a sociedade brasileira? Isso precisa ser uma agenda coletiva de professores e estudantes. Será que não deveríamos ocupar as escolas, as salas de aula, na modalidade remota, de maneira a institucionalizar uma reflexão com os estudantes sobre essa realidade? Como fazer para pensar, conversar, sensibilizar e encontrar COM ELES, com os estudantes, saídas criativas para esse buraco em que estão tentando enterrar a educação brasileira? Se isso não for feito, o abismo que separa ricos e pobres, no Brasil, ficará cada vez mais próximo do intransponível. Que angústia. 
Das narrativas escolhidas, destacamos para reflexão alguns pontos que são recorrentes em outras narrativas e foram bem elaborados pelos praticantes acima. O aumento da jornada de trabalho, a solidariedade entre docentes, a aprendizagem constante ao longo desse período, a tentativa de absorver bons sentimentos a partir das diferentes experiências, como é gratificante para os professores ver a realização dos alunos e a colaboração com os estudantes para encontrar saídas criativas para a educação.

Ao longo da conversa com os dados, traremos outras narrativas que contribuem para ampliar o nosso olhar sobre as temáticas abordadas ao longo da pesquisa. Apresentaremos quatro criações públicas de professores de contextos e realidades diversas para dialogar sobre diferentes tipos de proposições e ambiências formacionais que podem ser encontradas na docência remota:

Figura 3 - Criação docente durante o distanciamento social: jogos

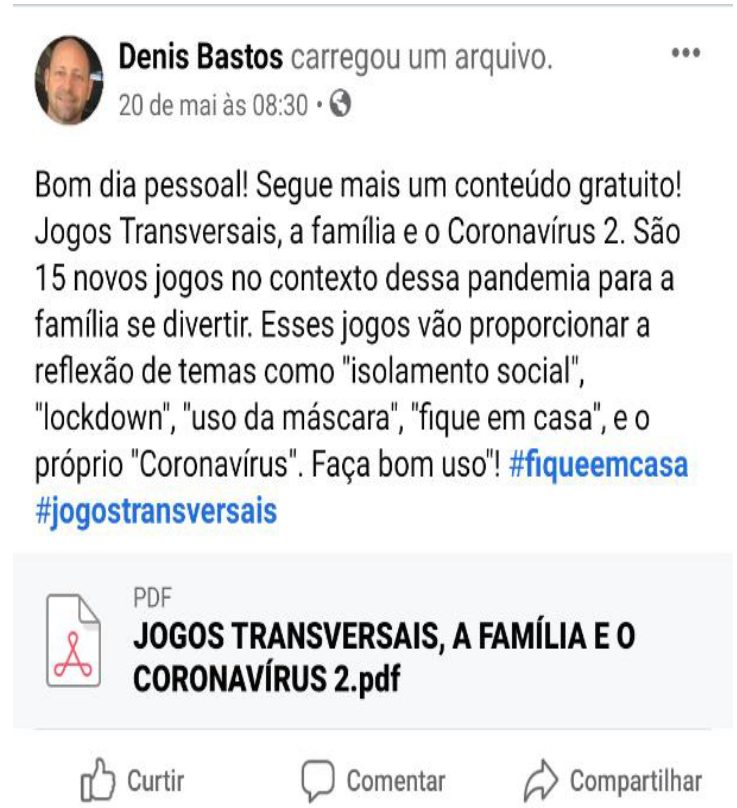

Fonte: grupo "PROFESSORES E PROFISSIONAIS DA EDUCAÇÃO RJ” no Facebook. 
Figura 4 - Criação docente durante o distanciamento social: exercícios

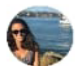

\section{Flávia Sb}

10 de jun às 07:21 •

[Recomendação] Uma ferramenta grátis que permite montar exercícios e listas de vários tipos! Já vem formatado e pronto para mandar para os estudantes. Achei bem prático! Espero que gostem $(*)$

https://gerador-de-atividades-seneca.netlify.app/

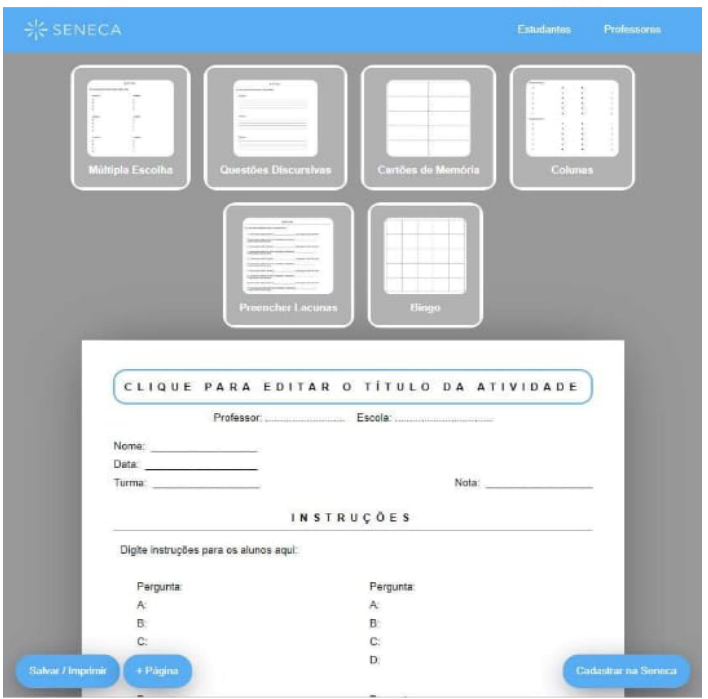

008

11 compartilhamentos

Fonte: Autoria de Flávia Belham no grupo "Vagas para educador: Professor, Instrutor ,tutor, D.I,

Conteudista, Pedagogo" no Facebook. Para mais autorias acesse www.senecalearning.com
Figura 5 - Criação docente durante o distanciamento social: gamificação

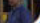

Tiago Eugênio compartilhou uma publicação

18 de mai às $07: 42 \cdot 0$

\section{PROFESSORES,}

Criei uma atividade de escape room para esse dia tão importante para nossas crianças e adolescentes.

Segunda-feira, 18 de maio, é o Dia Nacional de Combate ao Abuso e à Exploração Sexual Infantil.

Você sabia que o Brasil ocupa a segunda posição no ranking de países com maior número de ocorrências de Exploração Sexual Infantil, segundo a The Freedom Fund? E em tempos de necessário isolamento social maior invisibilidade das crianças em suas famílias e comunidades, esse tema ganha ainda mais importância.

Pensando nisso, criei uma atividade que pode ser replicada com seus alunos, de maneira que eles descubram um número que pode salvar vidas!

Faça bonito, professor!

Acesse: https://bit.ly/escape-combate senha: disque

Tempo: $25 \mathrm{~min}$

para mais escapes, siga-me no instagram: @tiagoeugenio20

Fonte: grupo "Ensino na pandemia - Ciência e cia" no Facebook. 
Figura 6 - Criação docente durante o distanciamento social: escrita e desenho

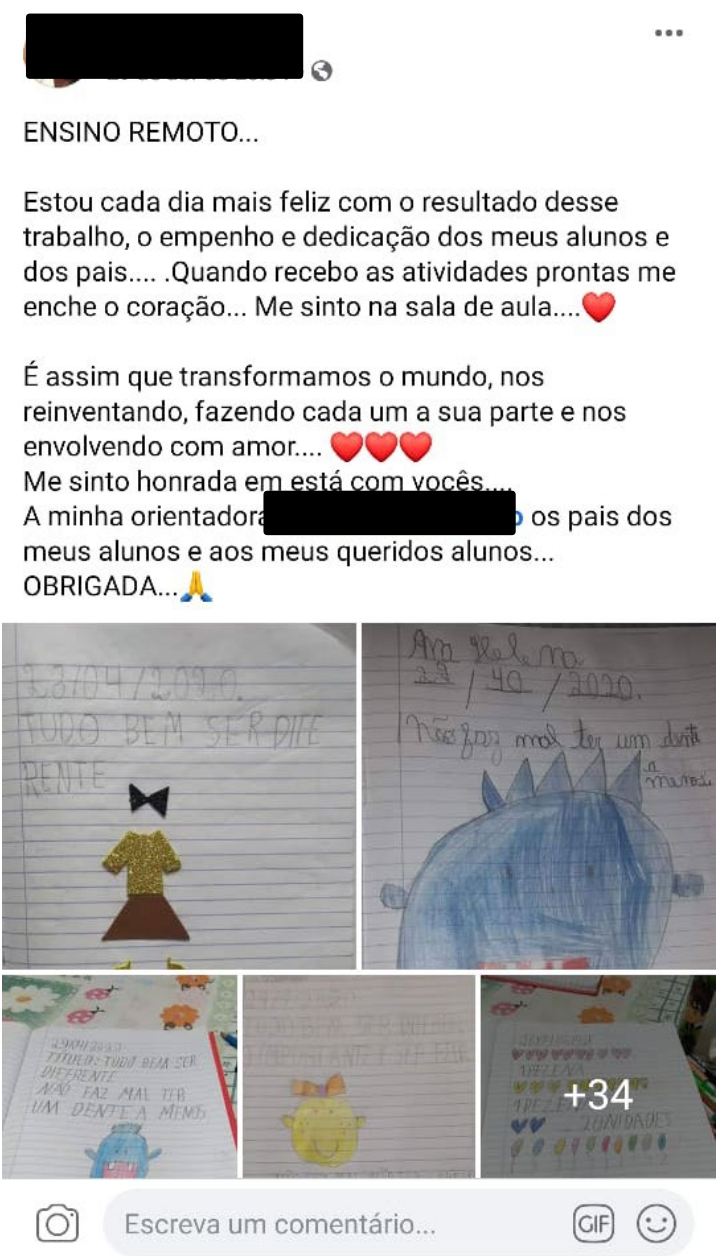

Fonte: postagem pública no Facebook.

As quatro atividades foram criadas com intencionalidades diferentes, a primeira é um jogo que envolve a família e aborda como temática o Coronavírus. A segunda é uma dica de interface gratuita para a criação de exercícios. A terceira é uma atividade gamificada no escape room, a respeito do dia nacional de combate ao abuso e à exploração sexual infantil. E a última, que não é praticada exatamente no ciberespaço, apesar de utilizar a internet como meio de comunicação com os pais, é uma expressão artística dos alunos em papel e apresenta como temática a diferença, com o título: tudo bem ser diferente. Vale ressaltar a importância de todas as temáticas abordadas pelos docentes, entre as pesquisas realizadas, as quais se destacam pelo compartilhamento de saberes, proposta de conhecimento aberto, inventividade, criatividade, emoção no compartilhamento, boa utilização das interfaces tecnológicas e ultrapassam a mera “proposição de tarefas” para atividades que visem a reflexão para a cidadania.

Amaral (2014) acredita que "experiências formativas e agenciamentos de comunicação promovem autorias docente e discente" (p. 132). Concordamos com a afirmação, consideramos 
o conceito de autoria como fundamental para pensar a ressignificação do trabalho docente no momento atual e o sentido que está sendo dado por eles nas atividades propostas. O entrelaçamento entre as ambiências formacionais e as tecnologias digitais em rede proporcionam múltiplas possibilidades autorais.

Segundo Dias (2010, p.56), “o uso de novas tecnologias possibilita a abolição das tradicionais grades curriculares, cuja organização dos saberes é fragmentada, com currículos lineares, pressupondo etapas a serem vencidas". As tecnologias na escola podem tornar a relação de aprendizagemensino mais atraente para os jovens, interdisciplinar, com um olhar direcionado para a autoria, a cidadania, a cultura contemporânea e um currículo integrado entre si e com as questões da sociedade em que as escolas estejam inseridas. Esse é um novo desafio para a educação, justamente porque essas tendências sugerem que a escola reorganize seu modelo de ensino, ponto que abordaremos com mais entusiasmo adiante.

A Fundação Carlos Chagas (2020), em parceria com a UNESCO do Brasil e com o Itaú Social, desenvolveu uma pesquisa para investigar como os professores brasileiros das redes públicas e privadas ensinavam remotamente ao longo da pandemia, denominada Educação escolar em tempos de pandemia na visão de professoras/es da Educação Básica, a pesquisa apresenta diferentes focos e resultados, e apresentamos a seguir somente o gráfico que tem relação com a nossa pesquisa.

Figura 7 - Estratégias educacionais utilizadas por professores

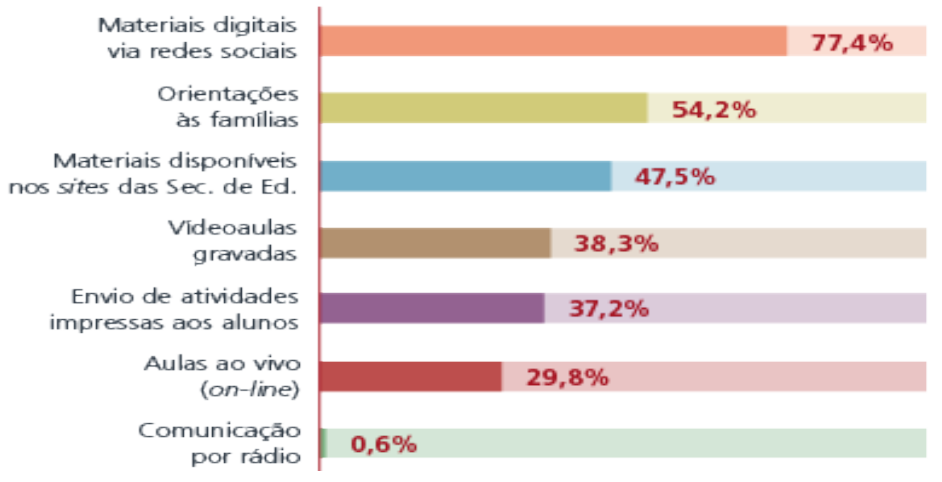

Fonte: https://www.fcc.org.br/fcc/educacao-pesquisa/educacao-escolar-em-tempos-de-pandemia-informe-n$\underline{1 \text { utm_source=mailpoet\&utm_medium=email\&utm_campaign=Informe-1-primeiros-resultados }}$

Pode-se observar, a partir do gráfico, que a maior parte dos professores investigados utiliza materiais digitais e envia por redes sociais, $77,4 \%$. Dentre eles, $38,3 \%$ grava videoaulas, $37,2 \%$ envia atividades impressas e $29,8 \%$ realiza aulas ao vivo com os estudantes. O foco das criações docentes continua sendo para a produção de conteúdo, a pesquisa não apresentou nos resultados uma opção que considerasse um espaço de socialização e interatividade como 
possibilidade para comunicação sobre os materiais produzidos pelos docentes, proporcionando o diálogo. Não sabemos precisar se os professores não consideraram tal fator em suas respostas ou se a pesquisa não contava com essa opção. De toda forma, os números nos alertaram para a inexistência desse requisito tão importante para o processo educativo, seja por parte dos idealizadores da pesquisa, seja por parte dos respondentes.

Constatamos em nossas pesquisas que a lógica conteudista da educação, com foco na produção de conteúdo, o que Paulo Freire (1987) chama de "educação bancária", tem sido recorrente no ensino remoto emergencial. Diante de algumas propostas de transposição didática de conteúdos da educação presencial para a não presencial, há um olhar direcionado para a transmissão e não para processos de subjetivação, diálogo e reflexão. Não queremos, com tal comentário, generalizar e afirmar que todas as práticas são assim. Afinal, iniciamos nossa conversa com os dados apresentando atividades que deslocam esse olhar. Contudo, gostaríamos de alertar e compartilhar outras possibilidades. Freire (1987, p. 40) acredita que o educador problematizador "re-faz, constantemente, seu ato cognoscente, na cognoscibilidade dos educandos. Estes, em lugar de serem recipientes dóceis de depósitos, são agora investigadores críticos, em diálogo com o educador, investigador crítico, também". A esse respeito, dialogamos com a praticante Daniele Grazinoli, servidora na UFRJ e militante da defesa da educação pública estatal socialmente referenciada.

Daniele Grazinoli - Muito bom ler sobre experiências. As suas, as da Ana Elisa, de todas/os. É indiscutível que são diversas as possibilidades de utilização das TIs, mas raramente discutimos as dimensões éticas, estéticas e políticas desses encontros e desencontros com as tecnologias. Talvez seja esse um desafio. Por exemplo, pensar qual a motivação de lançarmos mão das TIs nesse momento? Atender a demandas burocráticas, de manutenção de uma lógica conteudista, e que vai favorecer a lógica privatista da educação pública? $\mathrm{Ou}$ promover a comunicação como direito humano, criando redes de solidariedade e, quem sabe, iniciar um exercício de imaginação de outra ordem social com a socialização dos nossos repertórios e memórias, inclusive sobre a escola e a educação? Muita coisa é possível, mas o que nos convém? $\mathrm{O}$ fundamento das nossas iniciativas são inclusivos? Quem incluem e quem excluem? Quando? Por quê? Seu relato me fez imaginar como serão esses encontros exclusivamente à distância? Você experimentará?

Pensando com a narrativa da praticante, acreditamos ser importante abordar a lógica conteudista e a "pedagogia tradicional" em nossa análise. Freire (1987) chamou de "educação bancária" o método em que ao professor cabia a transmissão do conteúdo e aos alunos a escuta e a memorização, sem contestar, debater ou acrescentar. Dizemos "cabia”, no passado, mas não descartamos que hoje ainda possam ser encontrados no contexto do ensino remoto emergencial, métodos que se espelham na pedagogia tradicional. Por povoar a representação de escola que 
muitos possuem, ainda vemos pais exigindo esse método para a escolarização de seus filhos, professores que possuem essa concepção prévia de magistério e reproduzem a forma como foram escolarizados e tantos outros atores sociais que repercutem esse discurso. Não que uma aula expositiva não possa existir em algumas situações específicas, mas é preciso que esse não seja o único método utilizado.

Uma tal reflexão, que reconhecemos ser neste ensaio apenas sugerida, desde que realmente crítica, nos possibilita a compreensão, em termos dialéticos, das diferentes formas por que o homem conhece, nas suas relações com o mundo. Daí que se torne indispensável à superação da compreensão ingênua do conhecimento humano, na qual muitas vezes nos conservamos. Ingenuidade que se reflete nas situações educativas em que o conhecimento do mundo é tomado como algo que deve ser transferido e depositado nos educandos. Este é um modo estático, verbalizado, de entender o conhecimento, que desconhece a confrontação com o mundo como a fonte verdadeira do conhecimento, nas suas fases e nos seus níveis diferentes, não só entre os homens, mas também entre os seres vivos em geral (FREIRE, 2013, posição 258).

A defesa de Freire (2013) se contrapunha à pedagogia tradicional, propondo uma educação dialógica, crítica, reflexiva, estética, ética, e que respeitasse os saberes prévios dos estudantes. Concordamos com ele, por acreditarmos que a construção do conhecimento ocorra de uma forma mais efetiva mediante a socialização e as construções colaborativas, não separando o estudante da sua realidade. "Não há, por isso mesmo, possibilidade de dicotomizar o homem do mundo, pois que não existe um sem o outro" (FREIRE, 2013, posição 282). Ao propor que a construção do conhecimento ocorra mediante a confrontação com o mundo, Freire (2013) nos inspira a incentivar uma atitude curiosa do sujeito frente ao mundo, em uma busca constante por criar, com invenções para transformar o que está posto.

Acreditamos que o diálogo e a troca são fundamentais para a educação. Sendo assim, a proposta no presente artigo é de um entrelaçamento entre a educação, a comunicação e a tecnologia, considerando a importância que tais fatores adquirem na sociedade contemporânea e, em especial, em uma pandemia e talvez até no pós-pandemia. O conteúdo pode ser um dos componentes da aula, um artefato curricular, não a sua integralidade, a aula em si. Mas sem considerar qualquer teoria pedagógica como um salvacionismo, responsável por resolver todas as problemáticas existentes tanto no âmbito educacional, quanto fora dele. Como ponderamos anteriormente, propomos a reunião de diversas metodologias de ensino, selecionadas de acordo com o que o cotidiano da sala de aula apresenta.

Entendemos que estamos em um contexto extremo, em que as aulas remotas foram incluídas no cotidiano docente de forma emergencial, literalmente do dia para a noite. E diante 
disso, notamos que a superação e a resiliência da categoria docente é algo fora do comum. Gostaríamos de trazer uma imagem que tem circulado nas redes, personagem conceitual que nos proporcionou muitas reflexões sobre as criações docentes. Afinal, essa imagem nos alerta para uma dupla criação, a tecnológica e o saber técnico da disciplina a qual a professora ministra. Soma-se a isso a própria legenda da foto.

Figura 8 - Estratégias educacionais utilizadas por professores

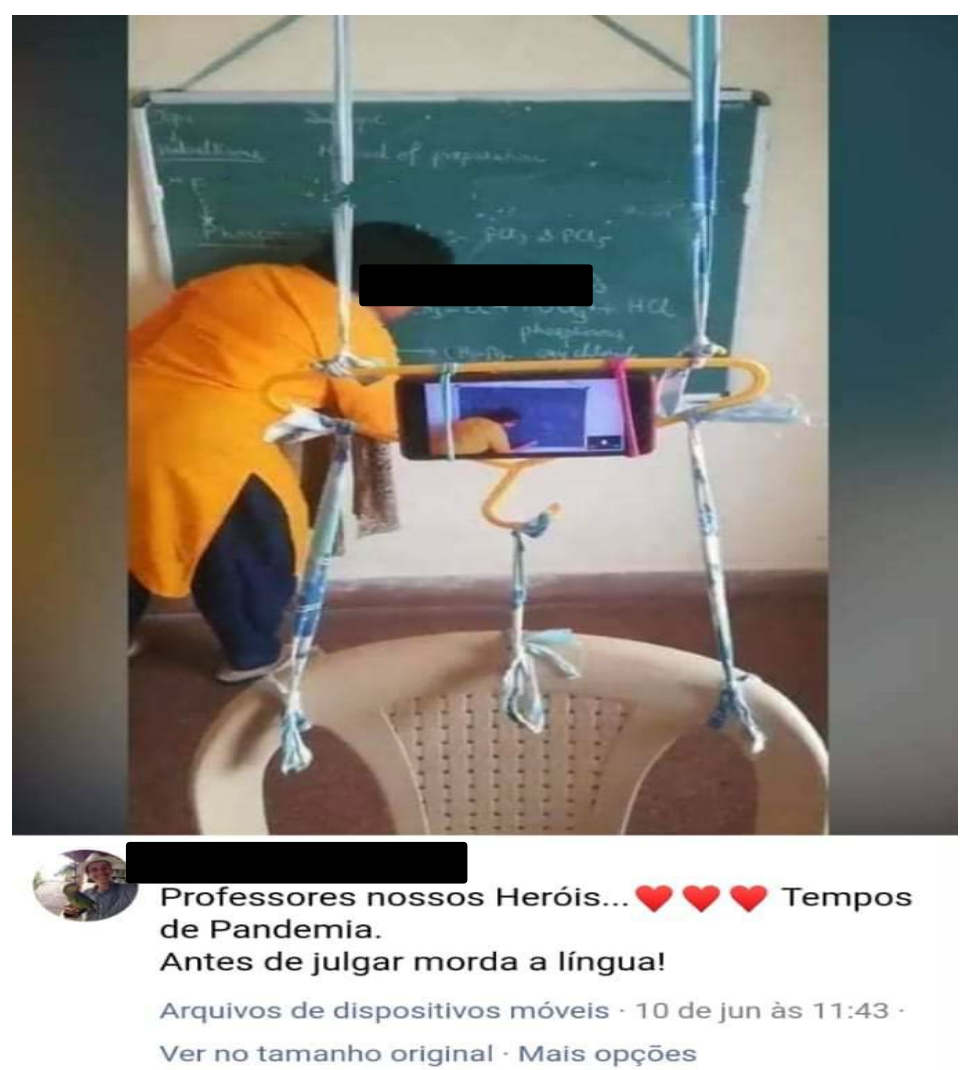

Fonte: postagem pública no Facebook.

De todas as aprendizagens que tivemos ao longo da pesquisa, uma das maiores é a ressignificação por que os profissionais de diversas áreas estão passando. Destacamos aqui os profissionais da educação, que diante do inesperado estão se redobrando para dar continuidade ao processo educativo de seus alunos, em um formato desconhecido por muitos deles. Com isso, esperamos que a área da educação note, com a mudança de atuação a que estamos sendo forçados nessa experiência social imposta pela pandemia, que a lógica conteudista e a pedagogia tradicional já pairavam pelas salas de aula e se intensificaram com o uso repentino das tecnologias para o ensino remoto. Precisamos pensar em outras lógicas, qualificando cada dia mais nossas práticas pedagógicas, já que o ensino remoto que, inicialmente, era emergencial, está perdurando mais do que alguns imaginavam. 
Praticante - Concordo. Num primeiro momento nos contentamos em resistir a enorme pressão para assumirmos uma EAD que se pretendia um sucedâneo à normalidade perdida. Resistimos. Era preciso atentar ao caráter altamente antidemocrático e até mesmo desumano dessas propostas que tornavam invisíveis as reais dimensões e efeitos sobre todos nós desse furacão. Uma visão mercadológica e produtivista nos empurrava e empurra para uma pedagogia que rejeitamos. Hoje começo a perceber que não basta resistir é preciso EXIGIR também, para que possamos começar a delinear novos mundos. $\mathrm{O}$ acesso à internet, a computadores passou a ser essencial. Muito investimento público tem que ser feito nessa direção. Nossa formação, como professores precisa mudar. Gostei de pensar um semestre apenas para esse começo. E a mudança não pode ser instrumental, não se trata apenas de transformar os meios. Os fins também precisam mudar. Como pensar as artes da presença: o teatro a dança nesse novo mundo que se delineia? Professora de artes cênicas, como vencer a melancolia que nos invade só em pensar num ensino baseado na distância entre os corpos. Precisamos nos preparar, compreender que perspectivas podem se abrir em meio a tantas perdas. Não podemos deixar de ter tempo para novas descobertas. Elas precisam ser feitas em conjunto com nossos alunos. Temos que apreender juntos a reinventar a vida é as artes. precisamos estar juntos nessa empreitada com muito recursos e a alma na mão. Resistir e Exigir!

Destacamos a frase da praticante acima: "precisamos nos preparar, compreender que perspectivas podem se abrir em meio a tantas perdas. Não podemos deixar de ter tempo para novas descobertas". Sendo assim, pensamos que algumas ponderações conclusivas são necessárias para pontuar uma proposição de mudança ampla, com a reorganização da lógica da educação. Uma delas diz respeito à importância de que as interfaces tecnológicas utilizadas promovam construções conjuntas, potencializando o diálogo, em métodos inovadores e não a pura transmissão de conteúdos. Outra ponderação indica a necessidade de que o currículo esteja integrado com a realidade e as necessidades dos estudantes, de modo que suas vivências sejam pressupostos básicos para todas as idealizações educacionais e como a praticante afirma: "feitas em conjunto com nossos alunos".

Também apontamos a articulação de ações multidisciplinares que reúnam professores que pensem em uma proposta em comum ou até projetos que objetivem encontrar caminhos para problemas reais e atuais, de uma realidade próxima, proporcionando uma sensação de pertencimento. Somamos a esse debate a necessidade do pensamento crítico para a libertação e não o consumo passivo de informações bem como a autoria e a criatividade, indispensáveis para a cocriação em rede. Insistimos que esses são alguns aspectos fundamentais para a formação do cidadão apto para lidar com as diferenças, com seu papel em uma sociedade democrática e com o mundo que está por vir. Encaminhamos tais ideias para fins de 
encerramento, desejando uma grande transformação para o mundo pós-pandemia, uma virada, um inédito viável (FREIRE, 1987). Que seja um tempo de mudanças para a educação.

\section{Considerações finais}

Nossos cotidianos foram alterados para um festival de incertezas em meio a uma pandemia. Isso posto, uma inquietação nos atingiu, no sentido de compreender como os professores estavam lidando com as atividades não presenciais. O presente artigo buscou compreender, a partir das pesquisas com os cotidianos, as criações e as percepções de docentes vivenciando o ensino remoto imposto pelo distanciamento social. Para tanto, realizamos uma pesquisa científica e parte dela é apresentada neste estudo.

Iniciamos contextualizando como as tecnologias transversalizam nossas ações educacionais cotidianas, dentrofora da pandemia, já que elas se fazem cada vez mais presentes em nossas vidas, inclusive nos espaçostempos escolares. Consideramos, com a velocidade das transformações sociotécnicas, que aprendemos a todo instante, já que novas ambiências são propostas e as utilizamos culturalmente, sendo as tecnologias estruturantes da sociedade contemporânea. E nessa linha, frente ao desconhecido para muitos professores, o ensino remoto tem sido uma sucessão de tentativas com criações cotidianas, elas se constituíam nosso campo de interesse.

Analisamos inúmeras regulamentações publicadas pelos entes federativos, favoráveis ao ensino remoto, o que gerou diferentes reações por parte dos educadores. E como observamos, na maioria das vezes, em instâncias públicas e privadas, havia a obrigatoriedade de desenvolver processos educativos mediados pelas tecnologias, gerando sentimentos, desde desconforto, até a superação. Notamos que aulas pela internet, pela TV, pelo rádio, por apostilas físicas dentre tantas outras formas, revelam a enorme desigualdade desse país continental e são focadas no conteúdo, muitas sem interatividade.

Para entendermos as ações dos docentes, selecionamos os princípios das pesquisas com os cotidianos, como um farol de subjetividades para pensar os caminhos que seguiríamos para a produção do conhecimento em educação. A maneira como conversamos com os dados é uma ação delineada por tais pressupostos epistêmico-metodológicos e fazem com que valorizemos cada vez mais os relatos de nossos pares, professores ressignificando suas práticas em um contexto de excepcionalidade.

Por fim, apresentamos as narrativas dos praticantes e os resultados da pesquisa. Descobrimos com os relatos de educadores as dores e as maravilhas do educar remotamente, 
do interagir em rede, da transformação entre o caos e aprendemos muito lendo o que os professores têm a dizer e observando algumas de suas criações, que podem contribuir como inspiração para os leitores desse artigo. Pensamos que, com a transformação em todos os sentidos da vida, poderíamos refletir sobre uma educação outra e apresentamos alguns posicionamentos relacionados aos usos das interfaces tecnológicas potencializando o diálogo, como: um currículo integrado com as vivências cotidianas de todos os envolvidos, a necessidade do pensamento crítico e libertário para a formação do cidadão autor, criativo e pronto para lidar com as diferenças. Uma educação que não está tão distante de nosso horizonte, mas precisamos apostar na mudança. Dessa forma, deixamos o questionamento: vamos juntos nessa aventura incerta?

\section{Referências}

ALVES, N. Decifrando o pergaminho - o cotidiano das escolas nas lógicas das redes cotidianas. In: OLIVEIRA, I. B.; ALVES, N. (Org.). Pesquisa no/do cotidiano das escolas: sobre redes de saberes. Rio de Janeiro: DP\&A, 2001.

. Sobre movimentos das pesquisas nos/dos/com os cotidianos. In OLIVEIRA, I. B.; ALVES, N. (Orgs.). Pesquisa nos/dos/com os cotidianos das escolas - sobre redes de saberes. Rio de Janeiro: DP\&A, 2008.

ALVES, N.; ANDRADE, N. Histórias possíveis entre imagens: conhecimentos e significações na produção de vídeos em escolas. In: MARTINS, R. \& Educação. Santa Maria: Editora da UFSM, 2013. p. 135-151.

AMARAL, M. M. Autorias docente e discente: pilares de sustentabilidade na produção textual e imagética em redes educativas presenciais e online. $239 \mathrm{f}$. Tese de Doutorado em Educação e Cultura Contemporânea - Programa de Pós-graduação em Educação da Universidade Estácio de Sá, Rio de Janeiro, 2014.

ANDRADE, N.; CALDAS, A. N.; ALVES, Nilda Guimarães. Os movimentos necessários às pesquisas com os cotidianos - após muitas conversas acerca deles. In: OLIVEIRA, I. B.; PEIXOTO, L. F.; SÜSSEKIND, M. L. (Org.). Estudos do cotidiano, currículo e formação docente: questões metodológicas, políticas e epistemológicas. 1ed. Curitiba: CVR Editora, 2019, v. 1, p. 19-45.

CERTEAU, M. A invenção do cotidiano: artes de fazer. Petrópolis: Vozes, 1994.

COLACIQUE, R. Visualidades surdas na cibercultura: aprendizagens em rede. 2018. $242 \mathrm{f}$. Tese (Doutorado em Educação) - Faculdade de Educação, Universidade do Estado do Rio de Janeiro, Rio de Janeiro, 2018. 
DELEUZE, G.; GUATTARI, F. Os personagens conceituais. In DELEUZE, G.; GUATTARI, F.. O que é filosofia? Rio de Janeiro: Ed. 34, 1992: 81-109.

DIAS, R. A. Tecnologias digitais e currículo: possibilidades na era da ubiquidade. Revista de Educação do COGEIME, ano 19, n. 16, p. 56-64, janeiro/junho 2010.

DUARTE, R.; ELEÁ, I. Mídia-educação: teoria e prática. In: SANTOS, E. (org.). Mídias e tecnologias na educação presencial e a distância. Rio de Janeiro: LTC, 2016, p. 3-17.

FREIRE, P. Extensão ou comunicação? [recurso eletrônico] Tradução Rosiska Darcy de Oliveira. Rio de Janeiro: Paz e Terra, 2013.

. Pedagogia do oprimido. $17^{\mathrm{a}}$. ed. Rio de Janeiro, Paz e Terra, 1987.

FUNDAÇÃO CARLOS CHAGAS. Pesquisa: Educação escolar em tempos de pandemia na visão de professoras/es da Educação Básica. São Paulo, 2020. Disponível em:

<encurtador.com.br/PUX27> Acesso em: 18 jun. 2020.

GALEANO, E. El libro de los abrazos. Editora Siglo XXI, 2011.

GARCIA, A. Disciplina estética, currículo e cotidianos. Universidade do Estado do Rio de Janeiro. 8 ago. 2018. Notas de Aula.

GEERTZ, C. A interpretação das culturas. Rio de Janeiro: LTC, 1989.

G1. Estudantes, pais e professores narram 'apagão' do ensino público na pandemia; em 7 estados e no DF, atividade remota não vai contar para o ano letivo. Brasil, 2020. Disponível em: <encurtador.com.br/gjy17> Acesso em: 17 jun. 2020.

LEFEBVRE, H. A vida cotidiana no mundo moderno. S. Paulo: Ática, 1992.

MACEDO, R. S.; GALEFFI, D.; PIMENTEL, Á. Um rigor outro sobre a qualidade na pesquisa qualitativa: educação e ciências humanas. Salvador: EDUFBA, 2009. 174 p.

MINISTÉRIO DA EDUCAÇÃO. Nota Técnica No 32/2020/Assessoria-GAB/GM/GM. Brasil, 2020. Disponível em: <encurtador.com.br/esGK6> Acesso em: 16 jun. 2020.

PALFREY, J.; GASSER, U. Nascidos na era digital: entendendo a primeira geração de nativos digitais. Porto Alegre: Grupo A, 2011.

RESOLUÇÃO SME No 1.074, de 14 de abril de 2010. [on line] Disponível em: <encurtador.com.br/iWY37>. Acesso em: 15 maio 2019.

SALDANHA, C.; WERLANG, M. Educação ambiental: a contribuição das multimídias no ensino de geografia com ênfase no consumo. In: SANTOS, A.; MACHADO, J.; COLVERO, R. (Orgs.). Interdisciplinaridade nas ciências humanas: caminhos da pesquisa contemporânea. (livro eletrônico). 1. ed. Jaguarão: 2017.

SILVA, M. Sala de Aula Interativa. São Paulo: Edições Loyola, 2014 
SOUSA, R.; MOITA, F.; CARVALHO, A. (Orgs.). Tecnologias digitais na educação. [online] Campina Grande: EDUEPB, 2011.276 p. Disponível em < encurtador.com.br/fDS27>. Acesso em: 30 mai 2018.

UNESCO. Suspensão das aulas e resposta à COVID-19. Paris, 2020. Disponível em: <encurtador.com.br/iwCS3> Acesso em: 22 abr. 2020.

\footnotetext{
${ }^{\text {i }}$ Professora do Instituto Federal do Rio de Janeiro (IFRJ). Doutoranda e mestra em Educação (PROPED/ Universidade do Estado do Rio de Janeiro - UERJ), especialista em Planejamento, Implementação e Gestão da Educação a Distância pela Universidade Federal Fluminense (UFF), MBA em Gestão de Recursos Humanos (UFF) e Graduada em Pedagogia (UERJ). Membro do Grupo de Pesquisa Docência e Cibercultura - GPDOC. Email: vivian.martinst@gmail.com Rio de Janeiro, Brasil. ORCID: https://orcid.org/0000-0002-9983-1749

ii Graduada em Pedagogia pela UNIRIO, cursando pós-graduação em Educomunicação e Tecnologia (UNINTER). Professora de ensino fundamental na rede municipal da cidade do Rio de Janeiro desde 2008. E-mail: sanba4p@gmail.com . ORCID: https://orcid.org/0000-0001-7239-1619

iii Mestranda no Programa de Pós-Graduação em Educação, da Universidade do Estado do Rio de Janeiro (ProPEd/UERJ), linha Cotidianos, Redes Educativas e Processos Culturais. Membro do Grupo de Pesquisa Docência e Cibercultura - GPDOC. E-mail: michelle.viana.trancoso@gmail.com . ORCID: https://orcid.org/0000-0002-6048-6407

iv Tradução das autoras. No original: "De nuestros miedos nacen nuestros corajes y en nuestras dudas viven nuestras certezas. Los sueños anuncian otra realidad posible y los delirios otra razón. En los extravíos nos esperan los hallazgos porque es preciso perderse para volver a encontrarse."

v "Termo de Certeau (1994) para aquele que vive as práticas/táticas cotidianas." (ALVES, 2008, p. 10) vi http://portal.mec.gov.br/index.php?option $=$ com_docman\&view $=$ download\&alias=145011-pcp00520\&category slug $=$ marco-2020-pdf\&Itemid $=30192$

vii $\mathrm{http}$ //pesquisa.in.gov.br/imprensa/jsp/visualiza/index.jsp?data=01/06/2020\&jornal=515\&pagina=32

viii https://abmes.org.br/arquivos/documentos/nota-tecnica-mec-32-02062020.pdf

ix https://www.educacao.sp.gov.br/noticias/governo-lanca-aulas-em-tempo-real-por-tv-aberta-e-celularestudantes-da-rede-estadual/

${ }^{\mathrm{x}}$ https://cee.es.gov.br/Not\%C3\%ADcia/prorrogacao-de-prazo-resolucao-5447-2020

xi $\mathrm{https}$ //cee educacao mg gov br/

e

https://drive.google.com/file/d/1Zg_iPGLzUYJAUkP92latpgtcuBycf08e/view

xii $\mathrm{http}$ ://sinprominas.org.br/noticias/atencao-professoresas-trabalho-remoto-deve-respeitar-direitos-ja-garantidos/ xiii http://www.cee.ri.gov.br/deliberacoes/D_2020-376.pdf

xiv https://prefeitura.rio/educacao/aplicativo-da-sme-com-material-para-alunos-estudarem-durante-suspensaodas-aulas-ultrapassa-os-600-mil-acessos/

${ }^{\mathrm{xv}}$ https://sites.google.com/view/mdc-anos-iniciais-8cre/anos-iniciais

xvi https://www1.folha.uol.com.br/educacao/2020/05/professores-pais-e-entidades-procuram-justica-contraobrigatoriedade-do-ensino-remoto.shtml

xvii Adotamos tal forma de escrita inspirada em Alves (2008), para quem a escrita conjunta dos termos atua como um posicionamento contra a ciência moderna que separa as palavras como semelhantes, mas opostas entre si.
} 